\title{
Non-invasive measuring of the circulatory effect of afterload reduction in order to monitor the pharmacodynamic effect of drugs in normal volunteers
}

\author{
JAN BUCH, STIG WALDORFF, PETER BO HANSEN, OLE ØDER RASMUSSEN \\ From Cardiovascular Laboratory of Medical Department B, Rigshospitalet, Copenhagen, Denmark
}

SUMMARY In order to measure the effect of a decrease in afterload on systolic time intervals, left ventricular end-systolic diameter, and left ventricular wall stress, eight healthy young persons underwent a randomised placebo controlled trial of terbutaline before and during atenolol treatment. Pre-ejection period index, left ventricular end-systolic diameter, and wall stress all decreased after terbutaline, the decrease being clearly dose dependent. This was identical before and during atenolol administration. Consequently the observed changes were induced by beta- 2 elicited vasodilatation, possibly combined with some decrease of parasympathetic tone. A close correlation between changes in pre-ejection period index (PEPI) and changes in left ventricular end-systolic diameter (LVESD) and wall stress was shown both before and during atenolol treatment. When using non-invasive methods in the evaluation of changes in contractility, it is important to correct for changes in preload and afterload. For normal subjects it is suggested that the relation between $\triangle$ PEPI and $\triangle$ LVESD as a percentage of the mean values should be used for evaluation of afterload changes. A method is suggested for estimating changes in pre-ejection period index induced by changes in left ventricular end-systolic diameter or wall stress.

Systolic time intervals are very sensitive to changes in preload, afterload, pulse rate, and contractility. It is relatively simple to correct for changes in pulse rate. ${ }^{1}$ In order to be able to use systolic time intervals more confidently during pharmacological interventions it is essential to be able to estimate the degree of change which might be caused by changes in preload and afterload, before ascribing the results to changes in contractility. In a previous study we used simultaneously recorded systolic time intervals and echocardiographic variables in the evaluation of the circulatory effect of preload reduction, and found it possible to estimate the degree of change in pre-ejection period index, which was to be expected after changes in preload. ${ }^{2}$

Changes in afterload will mainly tend to atter left ventricular end-systolic volume, while left ventricular end-diastolic volume will only be changed to a minor degree. $^{3}$ Echocardiographically this should be recorded as changes mainly in the left ventricular

Supported by the Danish Heart Foundation.

Accepted for publication 3 May 1983 end-systolic diameter. Left ventricular end-systolic diameter, on the other hand, is relatively unchanged by changes in preload. ${ }^{45}$ Pre-ejection period index and pre-ejection period/left ventricular ejection time (PEP/LVET) are the systolic time intervals which are best correlated to changes in contractility.$^{67}$ These variables, however, tend to decrease both with a reduction in afterload ${ }^{8}$ and with an increase in contractility, ${ }^{6}$ besides the above mentioned preload induced changes. ${ }^{2}$ Terbutaline is a relatively specific beta-2 stimulator ${ }^{9}$ and will thus mainly tend to decrease afterload. At the same time a reflex increase in heart rate will take place.

The purpose of the present study was to measure changes in left ventricular end-systolic diameter and left ventricular systolic wall stress caused by afterload reduction by terbutaline, when given alone and after pretreatment with atenolol in an attempt to block the increase in heart rate, and to correlate these changes to changes in pre-ejection period and PEP/LVET.

When the effect of heart rate, preload, and afterload can be accounted for, it is assumed that residual changes in pre-ejection period index and PEP/LVET are caused by changes in contractility. 
Table 1 Heart rate, systolic and diastolic blood pressure, pulse pressure, and mean blood pressure before (control) and afier injections of terbutaline and saline, and during treatment with atenolol (mean $\pm S D$ )

\begin{tabular}{|c|c|c|c|c|c|c|c|c|c|c|}
\hline \multirow[t]{2}{*}{$\begin{array}{l}\text { Terbutaline dose } \\
(\mu \mathrm{gg})\end{array}$} & \multicolumn{2}{|c|}{ Heart rate/min } & \multicolumn{2}{|l|}{$\begin{array}{l}\text { Systolic BP } \\
\text { (mmHg) }\end{array}$} & \multicolumn{2}{|c|}{$\begin{array}{l}\text { Diastolic BP } \\
(m m H g)\end{array}$} & \multicolumn{2}{|c|}{$\begin{array}{l}\text { Pulse pressure } \\
\text { (mmHg) }\end{array}$} & \multicolumn{2}{|l|}{$\begin{array}{l}\text { Mean BP } \\
(m m H g)\end{array}$} \\
\hline & Terbutaline & Saline & Terbutaline & Saline & Terbutaline & Saline & Terbutaline & Saline & Terbutaline & Saline \\
\hline $\begin{array}{l}\text { Before and after } i \\
\text { Control } \\
0.5 \\
1.0 \\
2.0 \\
4.0\end{array}$ & $\begin{array}{l}\text { jections of terb } \\
66 \pm 10 \\
68 \pm 10 \\
70 \pm 11 \\
77 \pm 14 \dagger \\
90 \pm 16 \dagger\end{array}$ & $\begin{array}{l}\text { butaline ar } \\
67 \pm 12 \\
64 \pm 11 \\
65 \pm 12 \\
65 \pm 12 \\
65 \pm 11\end{array}$ & $\begin{array}{l}\text { saline } \\
124 \pm 11 \\
128 \pm 10 \\
129 \pm 11^{\star} \\
138 \pm 11 \dagger \\
145 \pm 14 \dagger\end{array}$ & $\begin{array}{l}121 \pm 9 \\
121 \pm 10 \\
121 \pm 9 \\
121 \pm 11 \\
123 \pm 10\end{array}$ & $\begin{array}{l}80 \pm 5 \\
74 \pm 6 \\
72 \pm 5+ \\
72 \pm 6 \dagger \\
64 \pm 5 \dagger\end{array}$ & $\begin{array}{l}77 \pm 6 \\
77 \pm 6 \\
78 \pm 8 \\
76 \pm 6 \\
81 \pm 8\end{array}$ & $\begin{array}{l}44 \pm 9 \\
53 \pm 10+ \\
58 \pm 11+ \\
66 \pm 84 \\
81 \pm 16+\end{array}$ & $\begin{array}{l}44 \pm 6 \\
44 \pm 12 \\
44 \pm 11 \\
44 \pm 9 \\
42 \pm 7\end{array}$ & $\begin{array}{l}96 \pm 5 \\
93 \pm 6 \\
91 \pm 5 \\
95 \pm 7 \\
91 \pm 6\end{array}$ & $\begin{array}{l}92 \pm 7 \\
92 \pm 5 \\
93 \pm 7 \\
91 \pm 7 \\
95 \pm 8\end{array}$ \\
\hline $\begin{array}{l}\text { During treatment } \\
\text { Control } \\
0.5 \\
1.0 \\
2.0 \\
4.0\end{array}$ & $\begin{array}{l}\text { ith atenolol } \\
55 \pm 10 \\
57 \pm 10 \\
60 \pm 11 \dagger \\
64 \pm 10+ \\
74 \pm 12 \dagger\end{array}$ & $\begin{array}{l}55 \pm 9 \\
53 \pm 8 \\
52 \pm 9 \\
54 \pm 10 \\
54 \pm 11\end{array}$ & $\begin{array}{l}114 \pm 7 \\
116 \pm 11 \\
118 \pm 8 \\
121 \pm 10+ \\
132 \pm 10 \dagger\end{array}$ & $\begin{array}{l}116 \pm 6 \\
115 \pm 8 \\
115 \pm 5 \\
118 \pm 4 \\
119 \pm 5\end{array}$ & $\begin{array}{l}69 \pm 7 \\
71 \pm 8 \\
67 \pm 5 \\
64 \pm 6 \\
61 \pm 4^{\star}\end{array}$ & $\begin{array}{l}71 \pm 7 \\
71 \pm 7 \\
72 \pm 3 \\
74 \pm 5 \\
75 \pm 3\end{array}$ & $\begin{array}{l}45 \pm 7 \\
44 \pm 7 \\
51 \pm 11 \star \\
57 \pm 11 \dagger \\
71 \pm 13\end{array}$ & $\begin{array}{l}44 \pm 7 \\
44 \pm 6 \\
43 \pm 6 \\
44 \pm 6 \\
44 \pm 6\end{array}$ & $\begin{array}{l}84 \pm 6 \\
86 \pm 9 \\
84 \pm 4 \\
83 \pm 5 \\
85 \pm 2\end{array}$ & $\begin{array}{l}87 \pm 5 \\
86 \pm 4 \\
86 \pm 2 \\
89 \pm 3 \\
90 \pm 2\end{array}$ \\
\hline
\end{tabular}

* Significantly different from control $p<0.05$.

t Significantly different from control $p<0.01$.

\section{Subjects and methods}

Eight normal healthy persons (four female and four male) aged 22 to 28 years (mean 24 years) were included in the study. Written informed consent was obtained. The design of the study was randomised double blind, and there were four different treatment schedules: (1) three days pretreatment with atenolol $100 \mathrm{mg}$ orally. Eight hours after the last dose an intravenous cannula was inserted and after 30 minutes rest basic measurements of systolic time intervals, left ventricular dimensions, and blood pressure were taken. An intravenous dose of $0.5 \mu \mathrm{g}$ terbutaline $/ \mathrm{kg}$ body weight was given and new measurements were taken after 10 minutes. Further intravenous doses of terbutaline $1 \mu \mathrm{g} / \mathrm{kg}, 2 \mu \mathrm{g} / \mathrm{kg}$, and $4 \mu \mathrm{g} / \mathrm{kg}$ were administered, with 10 minute intervals, and after each dose repeat measurements were performed. (2) As (1) but with injection of normal saline instead of terbutaline. (3) As (1) but without pretreatment with atenolol. (4) As (2) but without pretreatment with atenolol. Atenolol was used to inhibit reflex increase in heart rate and possible slight beta-l stimulation after terbutaline administration.

\section{HAEMODYNAMIC MEASUREMENTS}

Systolic time intervals were recorded and corrected for heart rate according to Weissler et al. ${ }^{1}$ The variables used were pre-ejection period index and preejection period/left ventricular ejection time (PEP/ LVET). By M-mode echocardiography left ventricular end-diastolic diameter, end-systolic diameter, and systolic posterior wall thickness were measured. Simultaneously, blood pressure was measured on the

Table 2 Systolic time intervals corrected for heart rate before (control) and after injections of terbutaline and saline and value obtained during treatment with atenolol (mean $\pm S D$ )

\begin{tabular}{|c|c|c|c|c|c|c|c|c|}
\hline \multirow[t]{2}{*}{$\begin{array}{l}\text { Terbutaline dose } \\
\text { ( } \mu \mathrm{g} / \mathrm{kg})\end{array}$} & \multicolumn{2}{|l|}{$\underset{(m s)}{Q S_{I I} I}$} & \multicolumn{2}{|l|}{$\begin{array}{l}\text { LVETI } \\
\text { (ms) }\end{array}$} & \multicolumn{2}{|l|}{$\begin{array}{l}\text { PEPI } \\
\text { (ms) }\end{array}$} & \multicolumn{2}{|c|}{$P E P / L V E T \times 10^{3}$} \\
\hline & Terbutaline & Saline & Terbutaline & Saline & Terbutaline & Saline & Terbutaline & Saline \\
\hline $\begin{array}{l}\text { Before and after } \\
\text { Control } \\
0.5 \\
1.0 \\
2.0 \\
40\end{array}$ & $\begin{array}{l}f \text { terbutaline a } \\
523 \pm 11 \\
518 \pm 8 \\
513 \pm 10^{\star} \\
506 \pm 11^{\star} \\
502 \pm 12^{\star}\end{array}$ & $\begin{array}{l}\text { saline } \\
528 \pm 16 \\
524 \pm 14 \\
528 \pm 13 \\
528 \pm 11 \\
530 \pm 10\end{array}$ & $\begin{array}{l}407 \pm 11 \\
412 \pm 9 \\
413 \pm 11 \\
413 \pm 9 \\
413 \pm 13\end{array}$ & $\begin{array}{l}412 \pm 16 \\
413 \pm 12 \\
413 \pm 14 \\
414 \pm 12 \\
415 \pm 11\end{array}$ & $\begin{array}{c}116 \pm 8 \\
107 \pm 6+ \\
99 \pm 7+ \\
93 \pm 7+ \\
88 \pm 5+\end{array}$ & $\begin{array}{l}116 \pm 10 \\
112 \pm 8 \\
115 \pm 10 \\
114 \pm 10 \\
116 \pm 9\end{array}$ & $\begin{array}{l}299 \pm 33 \\
264 \pm 25 t \\
240 \pm 31 t \\
215 \pm 30 t \\
196 \pm 29 t\end{array}$ & $\begin{array}{l}295 \pm 38 \\
280 \pm 29 \\
290 \pm 42 \\
287 \pm 37 \\
292 \pm 35\end{array}$ \\
\hline $\begin{array}{l}\text { Before and afier } \\
\text { Control } \\
0.5 \\
1.0 \\
2.0 \\
40\end{array}$ & $\begin{array}{l}\text { f terbutaline o } \\
518 \pm 13 \\
518 \pm 11 \\
519 \pm 12 \\
513 \pm 11 \\
510 \pm 12^{\star}\end{array}$ & $\begin{array}{l}\text { d saline dq } \\
523 \pm 15 \\
522 \pm 17 \\
525 \pm 15 \\
526 \pm 19 \\
524 \pm 16\end{array}$ & $\begin{array}{l}\text { treatment wi } \\
410 \pm 15 \\
413 \pm 14 \\
417 \pm 16+ \\
418 \pm 12 \dagger \\
420 \pm 10^{\star}\end{array}$ & $\begin{array}{l}\text { atenolol } \\
411 \pm 12 \\
410 \pm 11 \\
411 \pm 11 \\
412 \pm 16 \\
412 \pm 12\end{array}$ & $\begin{array}{l}109 \pm 14 \\
105 \pm 13 \\
102 \pm 13 t \\
95 \pm 104 \\
90 \pm 11 \dagger\end{array}$ & $\begin{array}{l}112 \pm 12 \\
113 \pm 11 \\
113 \pm 10 \\
114 \pm 8 \\
112 \pm 12\end{array}$ & $\begin{array}{l}273 \pm 58 \\
257 \pm 49 \star \\
245 \pm 53 t \\
223 \pm 40 t \\
204 \pm 43 t\end{array}$ & $\begin{array}{l}281 \pm 49 \\
284 \pm 33 \\
284 \pm 33 \\
286 \pm 25 \\
280 \pm 40\end{array}$ \\
\hline
\end{tabular}

$\star$ Significantly different from control $p<0.05$.

$\dagger$ Significantly different from control $p<0.01$.

QSIII, total electromechanical systole corrected for heart rate. 
Table 3 Left ventricular end-diastolic and end-systolic diameters and left ventricular wall stress before (control) and after injections of terbutaline and saline (mean $\pm S D$ )

\begin{tabular}{|c|c|c|c|c|c|c|}
\hline \multirow[t]{2}{*}{$\begin{array}{l}\text { Terbutaline dose } \\
(\mu g / \mathrm{kg})\end{array}$} & \multicolumn{2}{|l|}{$\begin{array}{l}\text { LVEDD } \\
(\mathrm{mm})\end{array}$} & \multicolumn{2}{|l|}{$\underset{(\operatorname{mom})}{L V E S D}$} & \multicolumn{2}{|l|}{$\underset{(d y m / c m)}{S}$} \\
\hline & Terbutaline & Saline & Terbutaline & Saline & Terbutaline & Saline \\
\hline \multicolumn{7}{|c|}{ Before and after injections of terbutaline and saline } \\
\hline $\begin{array}{l}\text { Control } \\
0.5 \\
1.0 \\
2.0 \\
4.0\end{array}$ & $\begin{array}{l}49 \pm 4 \\
49 \pm 4 \\
49 \pm 4 \\
49 \pm 4 \\
49 \pm 4\end{array}$ & $\begin{array}{l}49 \pm 4 \\
49 \pm 4 \\
49 \pm 4 \\
49 \pm 4 \\
49 \pm 4\end{array}$ & $\begin{array}{l}32 \pm 3 \\
31 \pm 3 \\
29 \pm 3+ \\
26 \pm 34 \\
24 \pm 24\end{array}$ & $\begin{array}{l}31 \pm 3 \\
31 \pm 3 \\
31 \pm 3 \\
31 \pm 3 \\
31 \pm 3\end{array}$ & $\begin{array}{l}54 \pm 11 \\
52 \pm 10 \\
45 \pm 8+ \\
40 \pm 10 \\
35 \pm 11\end{array}$ & $\begin{array}{l}54 \pm 13 \\
52 \pm 11 \\
52 \pm 11 \\
53 \pm 12 \\
54 \pm 12\end{array}$ \\
\hline \multicolumn{7}{|c|}{ Before and after injections of terbutaline and saline during treatment with atenolol } \\
\hline $\begin{array}{l}\text { Control } \\
0.5 \\
1.0 \\
2.0 \\
40\end{array}$ & $\begin{array}{l}49 \pm 4 \\
49 \pm 4 \\
49 \pm 4 \\
49 \pm 4 \\
50 \pm 4\end{array}$ & $\begin{array}{l}49 \pm 4 \\
49 \pm 4 \\
49 \pm 4 \\
49 \pm 4 \\
49 \pm 4\end{array}$ & $\begin{array}{l}31 \pm 3 \\
31 \pm 3 \\
30 \pm 4 \\
27 \pm 4 \\
25 \pm 3\end{array}$ & $\begin{array}{l}31 \pm 3 \\
31 \pm 2 \\
31 \pm 3 \\
32 \pm 3 \\
31 \pm 3\end{array}$ & $\begin{array}{l}46 \pm 5 \\
45 \pm 4 \\
42 \pm 9 \\
37 \pm 94 \\
33 \pm 7\end{array}$ & $\begin{array}{l}48 \pm 6 \\
46 \pm 6 \\
45 \pm 5 \\
49 \pm 5 \\
47 \pm 7\end{array}$ \\
\hline
\end{tabular}

+ Significantly different from control $p<0.01$.

LVEDD, left ventricular end-diastolic dimension; LVESD, left ventricular end-systolic dimension; S, left ventricular wall stress.

left arm using an Erkameter sphygmomanometer. Systolic wall stress was calculated using the formula:

$$
\mathrm{S}=\frac{0.334 \times \mathrm{P} \times \text { LVESD }}{\mathrm{H}(1+\mathrm{H} / \text { LVESD })} \times 10^{3} \mathrm{dyn} / \mathrm{cm},{ }^{10}
$$

where $S$ is systolic wall stress, $P$ is systolic pressure, and $\mathrm{H}$ is systolic wall thickness. All variables were measured without knowledge of the actual treatment. The reliability of the measured values has been reported previously. ${ }^{2}$

\section{STATISTICS}

Corresponding data for each individual were compared using Wilcoxon's test for paired data.

Correlations were calculated using least square linear correlation. When expressing percentage changes, regression towards the mean was avoided by conventional statistical methods. ${ }^{11}$

\section{Results}

The results are shown in Tables 1 to 3. None of the variables was significantly changed after saline injec- tion. Terbutaline increased the heart rate both when given alone and after pretreatment with atenolol. Systolic blood pressure increased and diastolic blood pressure decreased leading to an increase in pulse pressure while the mean blood pressure was virtually unchanged. This response was similar after atenolol pretreatment (Tables 1 to 3 ).

Pre-ejection period index and PEP/LVET decreased as expected when terbutaline was given alone and slightly less when given together with atenolol (Table 2).

Left ventricular end-diastolic dimension was unchanged while left ventricular end-systolic dimension and systolic wall stress decreased significantly after terbutaline. Atenolol alone decreased the wall stress partly because of a lower systolic pressure, and the response to terbutaline was attenuated by atenolol pretreatment (Table 3).

There was a very close linear correlation between $\Delta$ PEPI $\%$ or $\Delta$ PEP/LVET $\%$ and $\triangle$ LVESD $\%$ or $\Delta S \%$ which was identical when terbutaline was given alone or with atenolol. Even the correlation between $\Delta \mathrm{QS}_{\mathrm{II}} \mathrm{I} \%$ and $\Delta \mathrm{LVESD} \%$ or $\Delta \mathrm{S} \%$ was statistically

Table 4 Linear correlation coefficients between changes in left ventricular end-systolic diameter or left ventricular systolic wall stress and systolic time intervals both expressed as percentage changes from mean value, induced by terbutaline with and without atenolol treatment

\begin{tabular}{|c|c|c|c|c|}
\hline \multirow[t]{2}{*}{ STIAficioad } & \multicolumn{2}{|c|}{$\triangle L V E S D \%$} & \multicolumn{2}{|l|}{$\Delta S \%$} \\
\hline & Terbutaline & Terbutaline + Atenolol & Terbutaline & Terbutaline + Atenolol \\
\hline $\begin{array}{l}\Delta \text { QS I\% } \\
\Delta \text { LVETI \% } \\
\Delta \text { PEPI \% } \\
\triangle \text { PEP/LVET \% }\end{array}$ & $\begin{array}{l}0.802 t \\
0.274 \\
0.887 t \\
0.889 t\end{array}$ & $\begin{array}{l}0.711 \dagger \\
0.448 \\
0.780+ \\
0.789\end{array}$ & $\begin{array}{l}0.807 t \\
0.219 \\
0.866 t \\
0.860 t\end{array}$ & $\begin{array}{l}0.604 t \\
0.445^{\star} \\
0.708 t \\
0.720 t\end{array}$ \\
\hline
\end{tabular}

No statistically significant differences between terbutaline and terbutaline + atenolol values $(p<0.05)$

$\star$ Significantly different from 0 p $<0.01$.

+ Significantly different from 0 p $<0-001$. 

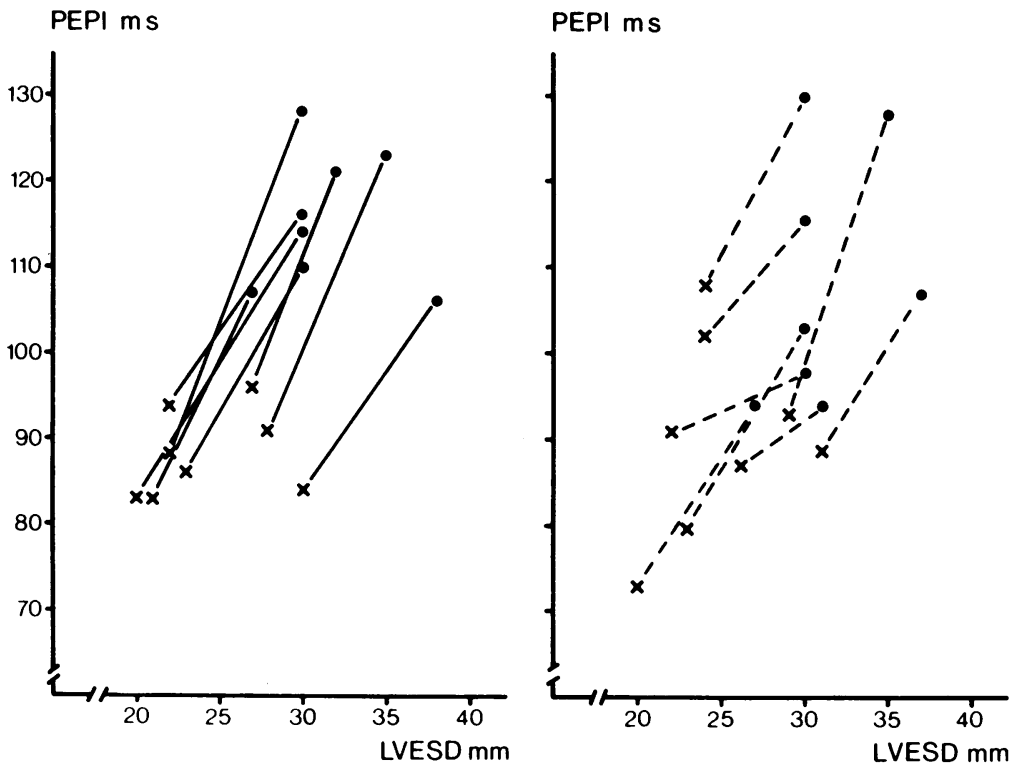

Fig. 1 Simultaneous measurements of left ventricular end-systolic diameter (LVESD) before ( $(\bullet)$ and afier $(X)$ injection of terbutaline (cumulative dose $7.5 \mu \mathrm{g} / \mathrm{kg}$ intravenously over a 40 minute period). Solid lines represent values obtained without atenolol treatment, and broken lines values obtained during atenolol treatment.
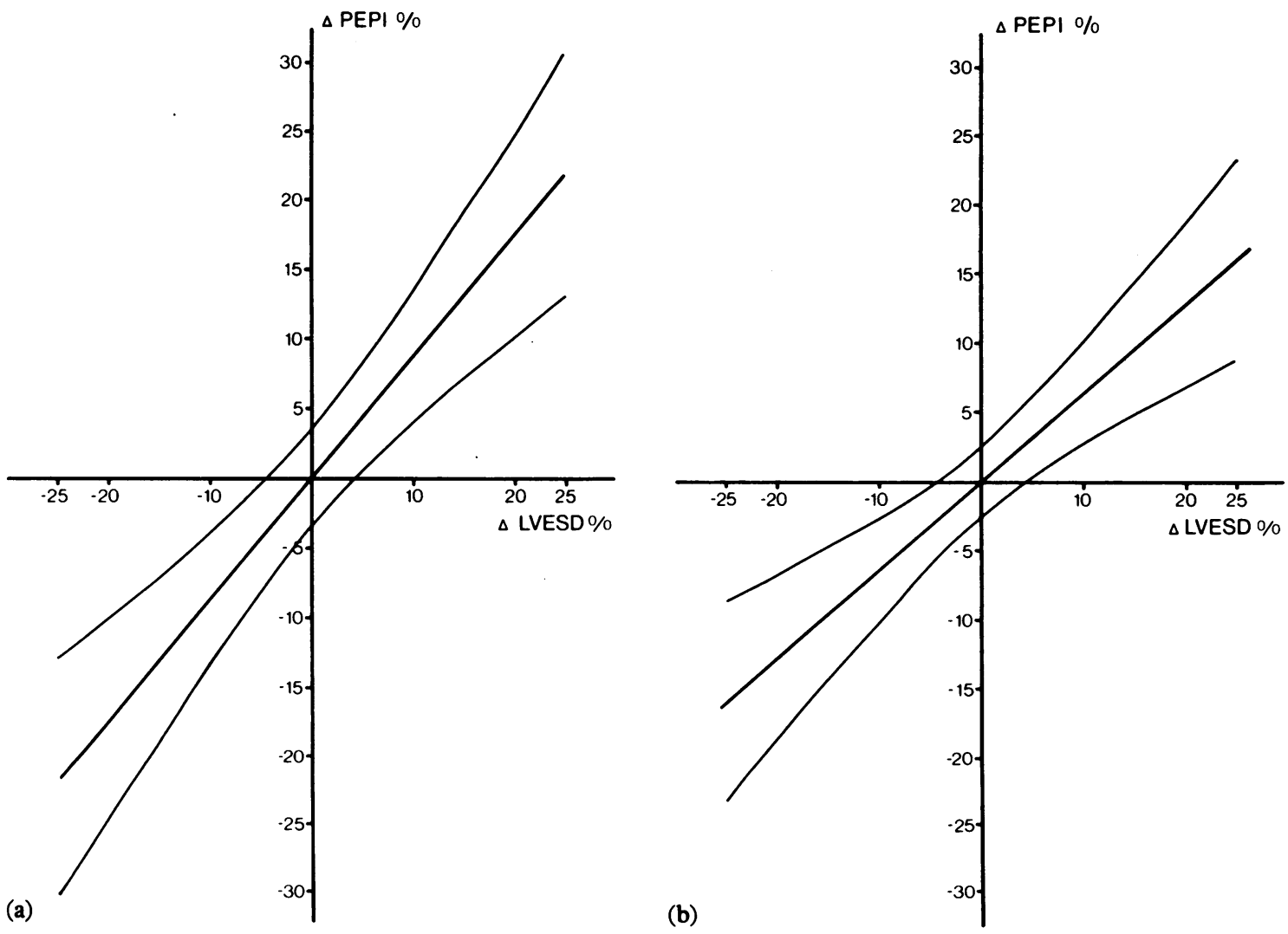

Fig. 2 (a) Calculated correlation between percentage change in pre-ejection period index (PEPI) and percentage change in left ventricular end-systolic diameter both expressed as change from mean values. The curved lines represent $95 \%$ confidence limits for the group. (b) Values obtained during atenolol treatment. 
significant (Table 4). Graphically the relation between pre-ejection period index and left ventricular endsystolic dimension is seen in Fig. 1. The relation between $\triangle$ LVESD as a percentage of the mean value and $\Delta$ PEPI as a percentage of the mean value is depicted in Fig. 2. The difference in the slope of the linear correlation when terbutaline was given and after atenolol pretreatment was not significant.

\section{Discussion}

Terbutaline is a relatively specific beta- 2 stimulator..$^{9}$ A single group of authors has suggested from indirect evidence that salbutamol, which resembles terbutaline, also possesses a positive inotropic effect (beta-1 stimulation), ${ }^{12}$ but according to most authors the beta-1 stimulation is negligible in the concentrations used in this study in comparison to the beta- 2 effect. ${ }^{913}$ Thus, it can be concluded that the observed changes are elicited by alterations in afterload.

Changes in heart rate and blood pressure seem to be minimal after treatment of asthma patients with nebulised terbutaline. ${ }^{14}$ 15 After oral, subcutaneous, intramuscular or intravenous treatment, however, heart rate and pulse pressure are increased as expected using a drug with a potent arteriolodilator effect. ${ }^{16-18}$ In patients with heart failure the effect on both heart rate and blood pressure is blunted. In this study an increase in heart rate of $36 \%(\mathrm{p}<0.01)$ was found and pulse pressure increased by $84 \%(p<0.01)$, while mean blood pressure remained relatively constant. The response to terbutaline after pretreatment with atenolol was greater than expected, suggesting that the reflex tachycardia is not so much the result of an increase in sympathetic activity as of a decrease in parasympathetic tone. This is compatible with the investigations of Man In 'TVeld et al ${ }^{19}$ who blocked the reflex tachycardia after diazoxide administration with atropine pretreatment. The degree of beta blockade obtained by the standard dosage of $100 \mathrm{mg}$ was not controlled by isoprenaline or exercise in the present study.

By echocardiography left ventricular end-diastolic dimension was found to be remarkably constant (Table 3). This might be because normal subjects took part in the experiment. In this case the filling pressure is initially low and will not decrease much despite a better emptying during systole, and so left ventricular end-diastolic dimension will remain constant in contrast to investigations on patients with heart disease where an improved emptying will reduce left ventricular end-diastolic pressure and thereby left ventricular end-diastolic dimension. This is compatible with some studies in cardiac patients where the major change is seen in left ventricular end-systolic volume, but still a significant decrease in left ven- tricular end-diastolic volume can be measured corresponding to a 2 to $3 \mathrm{~mm}$ decrease in left ventricular end-diastolic dimension. ${ }^{320}$ Major and very similar changes in wall stress and left ventricular end-systolic volume were recorded as expected.

The systolic time intervals with the closest correlation to invasive measurements of left ventricular function are pre-ejection period index and PEP/LVET. ${ }^{6} 7$ Furthermore, pre-ejection period index has a clear physiological background, representing the electromechanical delay plus the time necessary for the left ventricle to build up a pressure equal to the aortic pressure and will thus have a close inverse relation to $\mathrm{dP} / \mathrm{dt}^{21}$ Therefore, pre-ejection period index and PEP/LVET were the variables used in this study, and they decreased in accordance with results obtained by treatment of hypertension ${ }^{8}$ or from the opposite effect caused by increased afterload. ${ }^{22} 23$

This study showed the feasibility of correlating changes in cardiac function as measured by preejection period index and PEP/LVET with changes in left ventricular end-systolic dimension and systolic wall stress as indicators of afterload reduction after terbutaline administration. In a group of persons similar to those in this study, Fig. 2 may be used to estimate whether the haemodynamic effect of a drug can be explained by changes in afterload or contractility or both. For example, if a drug induces a decrease in left ventricular end-systolic dimension of $10 \%$ this may cause a decrease in pre-ejection period index of 4 to $13 \%$. Thus, only if a decrease in pre-ejection period index greater than $13 \%$ is encountered in this example is an additional mechanism such as increased myocardial contractility necessary to explain the results. This figure will not necessarily be valid for a group of patients with heart disease who have abnormal left ventricular compliance and size. No difference was found by using percentage systolic wall stress instead of percentage left ventricular endsystolic dimension, so in Fig. 2a and 2b we have used the latter as it is simpler.

The present study has shown a statistically significant correlation between a decrease in left ventricular end-systolic dimension or systolic wall stress and changes in pre-ejection period index or PEP/ LVET in normal subjects. This, together with a former study, ${ }^{2}$ may improve our ability to evaluate the haemodynamic effect of drugs non-invasively.

\section{References}

1 Weissler AM, Harris WS, Schoenfeld CD. Systolic time intervals in heart failure in man. Circulation 1968; 37: 149-59.

2 Buch J, Egeblad H, Hansen PB, Kjaergåd H, Waldorff $\mathrm{S}$, Steiness E. Correlation between changes in systolic 
time intervals and left ventricular diastolic diameter after preload reduction. Non-invasive monitoring of pharmacological intervention. Br Heart f 1980; 44: 668-71.

3 Quinones MA, Gaasch WH, Cole JS, Alexander JK. Echocardiographic determination of left ventricular stress-velocity relations in man. Circulation 1975; 51 : 689-700.

4 Rankin LS, Moos S, Grossman W. Alterations in preload and ejection phase indices of left ventricular performance. Circulation 1974; 51: 910-15.

5 Bugge-Asperheim B, Lekven J, Kiil F. Effect of saline infusion on stroke volume and end-systolic volume at various levels of adrenergic activity in dogs. Scand $\mathcal{F}$ Clin Lab Invest 1972; 29: 15-24.

6 Garrard CL Jr, Weissler AM, Dodge HT. The relationship of alterations in systolic time intervals to ejection fraction in patients with cardiac disease. Circulation 1970; 42: 455-62.

7 Ahmed SS, Levinson GE, Schwartz CJ, Ettinger PO. Systolic time intervals as measures of the contractile state of the left ventricular myocardium in man. Circulation 1972; 46: 559-71.

8 Dodek A, Burg JR, Kloster FE. Systolic time intervals in chronic hypertension: alterations and response to treatment. Chest 1975; 68: 51-5.

9 Persson H, Olsson T. Some pharmacological properties of terbutaline (INN), 1-(3.5-dihydroxyphenyl)2-(T-butyl-amino)-ethanol. A new sympathomimetic receptor stimulating agent. Acta Med Scand [Suppl] 1970; 512: 11-9.

10 Reichek N, Wilson J, Sutton MStJ, Plappert TA, Goldberg S, Hirshfeld JW. Noninvasive determination of left ventricular end-systolic stress: validation of the method and initial application. Circulation 1982; 65: 99-108.

11 Oldham PD. A note on the analysis of repeated measurements of the same subject. $f$ Chronic Dis 1962; 15: 969-77.

12 Sharma B, Goodwin JF. Beneficial effect of salbutamol on cardiac function in severe congestive cardiomyopathy. Circulation 1978; 58: 449-60.

13 Danilo P, Rosen TS. Effects of terbutaline on cardiac automaticity and contractility. F Clin Pharmacol 1982; 22: 223-30.

14 Simonsson BG, Stiksa J, Ström B. Double-blind trial with increasing doses of salbutamol and terbutaline aerosols in patients with reversible airways obstruction. Acta Med Scand 1972; 192: 371-6.

15 Hörnblad Y, Ripe E, Leideman T. Hexoprenaline and terbutaline administered by inhalation. Scand $\mathcal{Y}$ Respir Dis 1978; 59: 160-6.

16 Arner B, Bertler A, Karlefors T, Westling H. Circulatory effects of orciprenaline, adrenaline and a new sympathomimetic $\beta$-receptor stimulating agent, terbutaline, in normal human subjects. Acta Med Scand [Suppl] 1970; 512: 25-32.

17 Carlström S, Westling H. Metabolic, circulatory and respiratory effects of a new sympathomimetic $\beta$-receptor-stimulating agent, terbutaline, compared with those of orciprenaline. Acta Med Scand [Suppl] 1970; 512: 33-40.

18 Larsson S, Svedmyr N. Cumulative dose-response curves for early evaluation of bronchodilator drugs. Ann Allengy 1978; 41: 348-51.

19 Man In 'TVeld AJ, Wenting GJ, Boomsma F, Verhoeven RP, Schalekamp MADH. Sympathetic and parasympathetic components of reflex cardiostimulation during vasodilator treatment of hypertension. $\mathrm{Br} \mathcal{F}$ Clin Pharmacol 1980; 9: 547-51.

20 Slutsky R, Hooper W, Gerber K, Ashburn W, Curtis G, Karliner J. Left ventricular size and function after subcutaneous administration of terbutaline. Chest 1981; 79: 501-5.

21 Talley RC, Meyer JF, McNay JL. Evaluation of the pre-ejection period as an estimate of myocardial contractility in dogs. Am $\mathcal{F}$ Cardiol 1971; 27: 384-91.

22 Wallace AG, Mitchell JH, Skinner NS, Sarnoff SJ. Duration of the phases of left ventricular systole. Circ Res 1963; 12: 611-9.

23 Tarazi RC, Frohlich ED, Dustan HP. Left atrial abnormality and ventricular pre-ejection period in hypertension. Chest 1969; 55: 214-8.

Requests for reprints to Dr Jan Buch, Cardiovascular Laboratory of Medical Department B, Rigshospitalet, Blegdamsvej 9, Copenhagen $2100 \emptyset$, Denmark. 